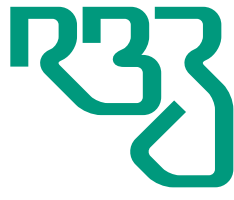

Revista

Brasileira de

Zootecnia

Brazilian Journal of Animal Science

ISSN 1806-9290

www.rbz.org.br

\section{Genetic assessment of seed yield-related traits in superior hybrids of Paspalum plicatulum $\times$ Paspalum guenoarum}

\author{
Rodrigo Ramos Lopes $^{1^{*}}$ iD, Lucia Brandão Franke ${ }^{1}$ iD, Cleber Henrique \\ Lopes de Souza $^{2}$ iD , Patricia Bertoncelli ${ }^{3}$ iD , Larissa Arnhold Graminho ${ }^{1}$ \\ Mariana Rockenbach de Ávila ${ }^{4}$ (iD), Emerson André Pereira ${ }^{5}$ (iD), Eder \\ Alexandre Minski da Motta $^{1}$ iD \\ ${ }^{1}$ Universidade Federal do Rio Grande do Sul, Faculdade de Agronomia, Departamento de \\ Plantas Forrageiras e Agrometeorologia, Porto Alegre, RS, Brasil. \\ ${ }^{2}$ University of Florida/IFAS, Agronomy Department, Forage Breeding and Genetics, \\ Gainesville, FL, United States of America. \\ ${ }^{3}$ Universidad de la Republica, Facultad de Agronomia, Departamento de Fitotecnia, \\ Montevideo, Uruguay. \\ ${ }^{4}$ Instituto Nacional de Tecnología Agropecuaria (INTA), Recursos Naturales, San Carlos de \\ Bariloche, Río Negro, Argentina. \\ ${ }^{5}$ Universidade Regional do Noroeste do Estado do Rio Grande do Sul, Departamento de \\ Estudos Agrários, Ijuí, RS, Brasil.
}

\begin{abstract}
*Corresponding author:
\end{abstract}
Received: April 15, 2019

Accepted: September 9, 2019

How to cite: Lopes, R. R.; Franke, L. B.; Souza, C. H. L.; Bertoncelli, P.; Graminho, L. A.; Ávila, M. R.; Pereira, E. A. and Motta, E. A. M. 2019. Genetic assessment of seed yield-related traits in superior hybrids of Paspalum plicatulum $\times$ Paspalum guenoarum. Revista Brasileira de Zootecnia 48:e20190075.

https://doi.org/10.1590/rbz4820190075

Copyright: This is an open access article distributed under the terms of the Creative Commons Attribution License (http://creativecommons.org/licenses/by/4.0/) which permits unrestricted use, distribution, and reproduction in any medium, provided the original work is properly cited.

\begin{abstract}
This study aimed to estimate the genetic parameters, genetic correlations, genetic dissimilarity, and predicted gains with the selection of interspecific apomictic Paspalum plicatulum $\times$ Paspalum guenoarum hybrids in relation to seed yield traits. Nineteen genotypes that showed increased forage yield in previous studies were planted in a randomized complete block design with ten blocks. Traits evaluated in this study were: number of tillers/plant, number of reproductive tillers/plant, number of racemes/inflorescence, number of seeds/inflorescence, weight of a thousand seeds, and seed yield. Data were analyzed using a mixed model approach. The genotypes evaluated in our study showed improvement potential in relation to high heritability $\left(\mathrm{H}_{\mathrm{g}}^{2}>0.50\right)$, high precision (Acgen $>90 \%$ ), and genetic dissimilarity (forming three groups) for seed yield traits. Seed yield showed high correlation to reproductive tillers that can be used as indirect selection tools for genetic improvement of seed yield.
\end{abstract}

Keywords: clustering analysis, genetic correlation, genetic gains, genetic parameters, REML/BLUP

\title{
Introduction
}

Apomixis is the predominant mode of reproduction in polyploid germplasms of the genus Paspalum, which has the largest number of apomictic species in the Poaceae family (Ortiz et al., 2013). The natural variation is blocked in apomictic species because apomixis results in genetically identical progeny derived from an unreduced, unfertilized egg cell (parthenogenesis) (Hand and Koltunow, 2014).

The presence of diploid plants of P. plicatulum in nature (Novo et al., 2017) shows an excellent potential to exploit natural variation by using sexual reproduction. Colchicine has been used for chromosome duplication in diploid plants of P. plicatulum (Sartor et al., 2009) to obtain a sexual tetraploid plant called " $4 \mathrm{c}-4 \mathrm{x}$ ", enabling the production of new hybrids through crossbreeding with compatible species.

Aguilera et al. (2011) artificially hybridized the sexual ecotype 4c-4x (female parent) with the apomictic cultivar "Rojas" of P. guenoarum (male parent) and obtained 23 interspecific hybrids. In a later study, 
Pereira (2013) performed artificial crosses between 4c-4x and the apomictic ecotypes of P. guenoarum called "Azulão" and "Baio". These ecotypes are native in subtropical regions of southern Brazil, showing cold tolerance, productive persistence (Steiner et al., 2017), and dry matter yield over $15 \mathrm{t} \mathrm{ha}^{-1}$ (Pereira et al., 2012).

Motta et al. (2016) and Motta et al. (2017) evaluated superior progenies resulting from hybridization between $P$. plicatulum $\times$ P. guenoarum species for two years in different places and showed the existence of genetic variability for different agronomic traits. The superior hybrids from these crosses resulted in total yield over $21 \mathrm{t} \mathrm{DM} \mathrm{ha}{ }^{-1}$ and leaf yield over $17 \mathrm{t} \mathrm{DM} \mathrm{ha}^{-1}$, showing the potential for improving cultivars for forage yield adapted to subtropical conditions.

Currently, strategies that include selection criteria such as agronomic traits and potential capacity to produce viable seeds are crucial for the dissemination of new cultivars (Lopes and Franke, 2011a). Seed production is a trait of great interest for forage species, as seed multiplication is economically relevant for new cultivars to be able to compete commercially (Boelt and Studer, 2010).

Therefore, the objectives of this study were to estimate genetic parameters, examine genetic correlations between traits, identify any existing genetic dissimilarity, and predict the genetic gains that could be obtained through the selection of superior hybrids of P. plicatulum $\times$ P. guenoarum in relation to their seed yield traits.

\section{Material and Methods}

The experiment was conducted in the 2014/2015 and 2015/2016 growing seasons in Eldorado do Sul $\left(30^{\circ} 05^{\prime} 52^{\prime \prime}\right.$ S, $51^{\circ} 39^{\prime} 08^{\prime \prime}$ W, $32 \mathrm{~m}$ asl), Rio Grande do Sul, Brazil. The climate is type Cfa, according to the Köppen classification system, with annual rainfall of $1440 \mathrm{~mm}$ (monthly average of $120 \mathrm{~mm}$ ). The soil was dystrophic Argisoil (Rhodustults, PVd) (Santos et al., 2013), with the following chemical characteristics: $\mathrm{pH}\left(\mathrm{H}_{2} \mathrm{O}\right)=5.6$; organic matter $(\mathrm{OM})=1.2 \% ; \mathrm{Al}^{3+}=0.0 \mathrm{cmol} \mathrm{dm}^{-3} ; \mathrm{Ca}^{+}=2.9 \mathrm{cmolc} \mathrm{dm}^{-3}$; $\mathrm{Mg}^{2+}=1.4 \mathrm{cmolc} \mathrm{dm}^{-3}$; and cation exchange capacity (CEC) $=8.4 \mathrm{cmolc} \mathrm{dm}^{-3}$.

The experimental area $\left(15 \mathrm{~m} \times 24 \mathrm{~m}=360 \mathrm{~m}^{2}\right)$ was corrected with $2500 \mathrm{~kg} \mathrm{ha}^{-1}$ of lime on July 7 , 2014. On October 2014, $290 \mathrm{~kg} \mathrm{ha}^{-1}$ of 5-20-20 fertilizer, $115 \mathrm{~kg} \mathrm{ha}^{-1}$ of $\mathrm{N}$ (urea), and $45 \mathrm{~kg} \mathrm{ha}^{-1}$ of $\mathrm{P}_{2} \mathrm{O}_{5}$ (triple superphosphate) were applied to meet the needs of perennial warm-season grasses (CQFS-RS/SC, 2004). In the second year, $30 \mathrm{~kg} \mathrm{ha}^{-1}$ of $\mathrm{N}$ (urea) and $75 \mathrm{~kg} \mathrm{ha}^{-1}$ of $\mathrm{P}_{2} \mathrm{O}_{5}$ (replenishment dose) were applied.

Nineteen apomictic genotypes of Paspalum were evaluated: four hybrids (10E104, 10E202, 10E2058, and 10E2084) resulting from the crossing between P. plicatulum 4c-4x and P. guenoarum Azulão, eight hybrids (10E3016, 10E3020, 10E3031, 10E3040, 10E3061, 10E3077, 10E3087, and 10E3093) from the cross between P. plicatulum 4c-4x and P. guenoarum Baio, four hybrids (H12, H13, H20, and $\mathrm{H} 22$ ) from the cross between P. plicatulum 4c-4x and P. guenoarum cv. Rojas, and two native ecotypes from the state of Rio Grande do Sul called Azulão and Baio. These genotypes stood out in previous studies due to their increased forage yield (Pereira et al., 2015; Huber et al., 2016; Motta et al., 2016; Motta et al., 2017).

Vegetative propagules were collected from two-year-old plants that were grown at the Experimental Station in Eldorado do Sul. Individually separated propagules (one tiller) were planted in $13 \times 8 \mathrm{~cm}$ containers with Carolina Soil ${ }^{\mathrm{TM}}$, a commercial substrate, composed of peat, vermiculite, organic residue, and limestone. This process took place between May and June 2014. Seedlings were kept in a greenhouse during the winter until it was time for them to be planted in the field (October 24, 2014). Before planting, the aerial parts of the tillers were cut to a uniform height of $0.15 \mathrm{~m}$, and the number of tillers was reduced to three tillers per genotype. In the second year, rejuvenation pruning was performed on all the genotypes (September 26, 2015) at a height of $0.15 \mathrm{~m}$.

Phenotyping was done prior to harvest, and the following traits were evaluated: TT - number of total tillers: direct count of all the tillers/plant; RT - reproductive tillers/plant: direct count of the tillers that 
formed inflorescences; and NRI - number of racemes/inflorescence: average number of racemes of six inflorescences from each genotype, randomly chosen.

Seeds were manually harvested when more than $50 \%$ of the inflorescences exhibited brown coloring and showed signs of dehiscence in caryopses. All inflorescences per plant were harvested (March 25, 2015 first year, and February 18, 2016 - second year). After seed harvesting, the following traits were assessed:

SY - seed yield/plant: the inflorescences collected were dried in a forced-air oven at $30^{\circ} \mathrm{C}$ for $72 \mathrm{~h}$ and manually threshed; sieves were used to remove impurities, and a De Leo $^{\mathrm{TM}}$ South Dakota seed blower (blower-motor: $1 / 3 \mathrm{HP}$; tube: $68.6 \times 10.2 \mathrm{~cm}$; aperture: $4.5-5.5 \mathrm{~cm}$; period: $2 \mathrm{~min}$.) was used to separate heavy and empty seeds. After cleaning, the pure seeds of each genotype were weighed on a precision balance (model Marte ${ }^{\mathrm{TM}} \mathrm{AD} 500$ ) and expressed in g;

WTS - weight of a thousand seeds: average weight of eight subsamples of 100 seeds, multiplied by 10 (Brasil, 2009);

and NSI - number of seeds/inflorescence, obtained from the following equation:

$$
\text { NSI }=\frac{\text { Sample weight of seeds } / \text { inflorescence } \times 1000}{\text { number of inflorescences } \times \text { WTS }}
$$

The sample weight of seeds/inflorescence was determined at harvest, when six intact inflorescences were separated from each genotype, manually threshed, processed, and individually weighed on a precision balance and expressed in $\mathrm{g}$.

The experiment consisted of 190 experimental units (single plant; spacing on the row and interrow of $1 \mathrm{~m}$ ) arranged under a randomized complete block design, with the nineteen genotypes arranged individually in 10 blocks. The data were analyzed using mixed model approach in the SELEGEN software (Resende, 2016), and estimates for genetic parameters were obtained. Genotypic values were predicted using the REML/BLUP procedure. The model used considered the randomized block design in one location and two harvests, according to Resende (2007):

$$
\mathrm{y}=\mathrm{Xm}+\mathrm{Zg}+\mathrm{Wp}+\mathrm{e},
$$

in which $\mathrm{y}$ is the data vector, $\mathrm{m}$ is the vector for the effects of measurement-repeat combinations (assumed as fixed) added to the general mean, $g$ is the vector of genotypic effects (assumed to be random), $\mathrm{p}$ is the vector of permanent environment effects (experimental units) (random), and e is the vector of errors or residuals (random). The capital letters (X, Z, and $\mathrm{W}$ ) represent the incidence matrices for the said effects ( $\mathrm{m}, \mathrm{g}$, and $\mathrm{p}$, respectively).

The structures of means and variances associated with the model are described by the following:

$$
\begin{gathered}
y \mid m, V \sim N(X m, V) \\
g \mid \sigma_{\mathrm{g}}^{2} \sim N\left(0, I \sigma_{\mathrm{g}}^{2}\right) \\
p \mid \sigma_{\mathrm{p}}^{2} \sim N\left(0, I \sigma_{\mathrm{p}}^{2}\right) \\
e \mid \sigma_{\mathrm{res}}^{2} \sim N\left(0, I \sigma_{\mathrm{res}}^{2}\right),
\end{gathered}
$$

in which $\mathrm{V}$ is the phenotypic covariance matrix; I is an identity matrix; and $\sigma_{\mathrm{g}}^{2} \sigma_{\mathrm{p}^{\prime}}^{2}$ and $\sigma_{\text {res }}^{2}$ are the genotypic, environmental, and residual variances, respectively.

The covariance between all the random effect models was assumed by the following:

$$
\operatorname{Cov}\left(\mathrm{g}, \mathrm{p}^{\prime}\right)=0 ; \operatorname{Cov}\left(\mathrm{g}, \mathrm{e}^{\prime}\right)=0 ; \operatorname{Cov}\left(\mathrm{p}, \mathrm{e}^{\prime}\right)=0
$$

The assumed distributions and mean structures (S) and variance (Var) were:

$$
\mathrm{S}\left[\begin{array}{c}
y \\
g \\
p \\
e
\end{array}\right]=\left[\begin{array}{c}
X m \\
0 \\
0 \\
0
\end{array}\right] ; \quad \operatorname{Var}\left[\begin{array}{c}
y \\
g \\
p \\
e
\end{array}\right]=\left[\begin{array}{cccc}
V & Z G & W C & R \\
G Z & G & 0 & 0 \\
C W & 0 & C & 0 \\
R & 0 & 0 & R
\end{array}\right],
$$


in which

$$
G=I \sigma_{\mathrm{g}}^{2}, R=I \sigma_{\mathrm{p}}^{2}, C=I \sigma_{\mathrm{e}}^{2} ; \mathrm{e}: V=Z I \sigma_{\mathrm{g}}^{2} \mathrm{Z}^{\prime}+W I \sigma_{\mathrm{p}}^{2} \mathrm{~W}^{\prime}+I \sigma_{\mathrm{e}}^{2}=\mathrm{ZGZ}^{\prime}+\mathrm{WCW}^{\prime}+\mathrm{R}
$$

The system of linear equations [mixed model equations (MME)] that were used to obtain the solutions of the model were:

$$
\left[\begin{array}{ccc}
X^{\prime} X & X^{\prime} Z & X^{\prime} W \\
Z X & Z Z+I \lambda_{1} & Z W \\
W^{\prime} X & W^{\prime} Z & W^{\prime} W+I \lambda_{2}
\end{array}\right]\left[\begin{array}{l}
\hat{m} \\
\hat{g} \\
\hat{p}
\end{array}\right]=\left[\begin{array}{c}
X^{\prime} y \\
Z^{\prime} y \\
W^{\prime} y
\end{array}\right],
$$

in which

$$
\lambda_{1}=\frac{\hat{\sigma}_{\mathrm{res}}^{2}}{\hat{\sigma}_{\mathrm{g}}^{2}}=\frac{1-\mathrm{H}_{\mathrm{g}}^{2}-\mathrm{c}^{2}}{\mathrm{H}_{\mathrm{g}}^{2}} ; \lambda_{2}=\frac{\hat{\sigma}_{\mathrm{res}}^{2}}{\hat{\sigma}_{\mathrm{p}}^{2}}=\frac{1-\mathrm{H}_{\mathrm{g}}^{2}-\mathrm{c}^{2}}{\mathrm{c}^{2}}
$$

The estimates of variances and genetic parameters are given as follows: genotypic variance $\left(\hat{\sigma}_{\mathrm{g}}^{2}\right)$, environmental variance $\left(\hat{\sigma}_{\mathrm{e}}^{2}\right)$, residual variance $\left(\hat{\sigma}_{\text {res }}^{2}\right)$, phenotypic variance $\left(\hat{\sigma}_{\mathrm{p}}^{2}=\hat{\sigma}_{\mathrm{g}}^{2}+\hat{\sigma}_{\mathrm{e}}^{2}+\hat{\sigma}_{\text {res }}^{2}\right)$, broad sense heritability $\left(\mathrm{H}_{\mathrm{g}}^{2}=\hat{\sigma}_{\mathrm{g}}^{2} / \hat{\sigma}_{\mathrm{g}}^{2}+\hat{\sigma}_{\mathrm{e}}^{2}+\hat{\sigma}_{\text {res }}^{2}\right)$, genetic variation coefficient $\mathrm{CV}=\sqrt{\hat{\sigma}_{\mathrm{g}}^{2}} \times 100 / \overline{\mathrm{X}}$, residual variation coefficient $\left(\mathrm{CV}_{\text {res }}=\sqrt{\hat{\sigma}_{\text {res }}^{2}} \times 100 / \overline{\mathrm{X}}\right)$, relative variation coefficient $\left(\mathrm{CV}_{\mathrm{r}}=\mathrm{CV}_{\mathrm{g}} / \mathrm{CV}_{\text {res }}\right)$, overall mean $(\overline{\mathrm{X}})$, and genetic accuracy in genotype selection (Acgen) as:

$$
\text { Acgen }=\left[\frac{\mathrm{b} \times \mathrm{H}_{\mathrm{g}}^{2}}{1+(\mathrm{b}-1) \times \mathrm{H}_{\mathrm{g}}^{2}}\right]^{1 / 2}
$$

in which b is number of blocks considering randomized complete block design (Resende and Duarte, 2007).

The genotypic values $(\mathrm{u}+\mathrm{g})$ of each genotype were obtained by adding each predicted genotypic effect (g) to the overall average of the experiment $(\mathrm{u})$. The genetic gain was the average of the predicted genetic effect vectors for the selected genotypes. The general average $(\mathrm{u})$ added to the genetic gain resulted in the new average of the genotypes $\left(\overline{\mathrm{X}}_{\text {new }}\right)$.

The significance of the random effects was obtained through Deviance Analysis, using the Restricted Maximum Likelihood (REML) method via Likelihood Ratio Test (LRT). The deviances were obtained as described by Resende (2016), using the model with and without the respective effects, subtracting the deviance obtained in the complete model, of the model without the effect, and compared to the value of the Chi-square $\left(\chi^{2}\right)$ at $1 \%$ probability, with one degree of freedom. The factor block, considered as fixed effect, was tested by the F test of Snedecor. Genetic correlation among traits were processed using model 102 of the SELEGEN software (Resende, 2016). Cluster analysis based on Ward's method using the Mahalanobis distance $\left(\mathrm{D}^{2}{ }_{\mathrm{ii}}\right.$ ) was performed using R software, version 3.5.2 (www.r-project.org).

\section{Results}

The deviance analysis (Anadev) revealed significant differences $(\mathrm{P}<0.01)$ among genotypes for all traits analyzed by the Chi-square test (Table 1). Thus, the respective variance components were significantly different from zero, as were the determination coefficients. The highest values were found in the genotypic effects of NSI, WTS, SY, and RT. The Anadev also showed significant differences through the F test $(\mathrm{P}<0.01)$ for the block effect in most traits, except for NRI ( $>>0.05)$, suggesting that the experimental design used in the genotype test was efficient in controlling the environmental heterogeneity between the blocks.

The highest estimates of genetic variance $\left(\hat{\sigma}_{\mathrm{g}}^{2}\right)$ were for NSI and RT, indicating that this germplasm had favorable conditions for the selection and improvement of these traits (Table 1). All genetic variances $\left(\hat{\sigma}_{\mathrm{g}}^{2}\right)$ were higher than the environmental variances $\left(\hat{\sigma}_{\mathrm{e}}^{2}\right)$, inferring that there was high experimental precision and low interference from the environment on the genotypes. For all traits evaluated in this study, the highest proportion of the phenotypic variance $\left(\hat{\sigma}_{\mathrm{p}}^{2}\right)$ was explained by genotype. 
Broad estimates of individual heritability $\left(\mathrm{H}_{\mathrm{g}}^{2}\right)$ ranged from 0.57 to 0.85 (Table 1). High values of $\mathrm{H}_{\mathrm{g}}^{2}$ were obtained for WTS, SY, NSI, and RT that corresponded with low standard deviations \pm \pm 0.11 to \pm 0.13 ), indicating that individual selection in Paspalum genotypes can be successful.

The genetic variation coefficient $\left(\mathrm{CV}_{\mathrm{g}}\right)$ among genotypes was higher than $10 \%$ for all traits and ranged from $10.91 \%$ (WTS) to $33.30 \%$ (SY) (Table 1). The residual variation coefficient $\left(\mathrm{CV}_{\text {res }}\right)$ of the traits was classified as of medium to low magnitude, which indicates that the experiment was conducted properly. The variation ranged from $4.61 \%$ (WTS) to $17.88 \%$ (RT), which are values accepted as precision coefficients for experimentation (Table 1). The relative variation coefficient $\left(\mathrm{CV}_{\mathrm{r}}\right)$, or the ratio between $\mathrm{CV}_{\mathrm{g}}$ and $\mathrm{CV}_{\text {res }}$, presented a genetic component $\left(\mathrm{CV}_{\mathrm{g}}\right)$ close to or higher than the environmental component $\left(\mathrm{CV}_{\text {res }}\right)$ with values ranging between 1.15 (TT) and 2.37 (WTS) (Table 1).

The selective accuracy (Acgen) ranged from 99.13\% (WTS and SY) to 96.43\% (TT), which are considered as high-precision values (Table 1). The high experimental rigor of this study shows that the selection of genotypes based on the tested traits will be reliable and safe.

Some traits presented positive and negative correlations regarding SY, which shows that they influenced the expression of this trait (Table 2). The trait that best correlated with SY was NSI $(r=0.794 ; \mathrm{P}<0.01)$, followed by RT $(r=0.769 ; P<0.01)$. Correlation NSI $\times$ NRI showed a positive and significant association between the traits $(r=0.598 ; \mathrm{P}<0.01)$, that is, when one increases, so does the other. However, other correlations of interest between WTS $\times$ NSI and WTS $\times$ SY had negative values $(r=-0.561$ and $r=-0.105$, respectively), but WTS $\times$ SY was not significant $(\mathrm{P}>0.05)$.

The cluster analysis using the Ward method, based on the Mahalanobis distance $\left(\mathrm{D}_{\mathrm{ii}}^{2}\right)$, distributed the nineteen evaluated genotypes into three distinct groups, according to their genetic dissimilarity (Figure 1 and Table 3). Cluster I ( $\left.C_{1}\right)$ was the most abundant and represented 73.7\% (14 genetically similar genotypes) of the total genotypes, namely, 10E3061, 10E3084, 10E3016, H12, 10E20104,

Table 1 - Values of verisimilitude (LRT) of deviance analysis (ANADEV) and estimates of genetic parameters (individual REML) for total tillers (TT, number plant ${ }^{-1}$ ), reproductive tillers (RT, number plant ${ }^{-1}$ ), number of racemes per inflorescence (NRI, number inflorescence ${ }^{-1}$ ), number of seeds per inflorescence (NSI, number inflorescence ${ }^{-1}$ ), weight of a thousand seeds (WTS, g) and seed yield (SY, g plant ${ }^{-1}$ ) in nineteen genotypes of Paspalum

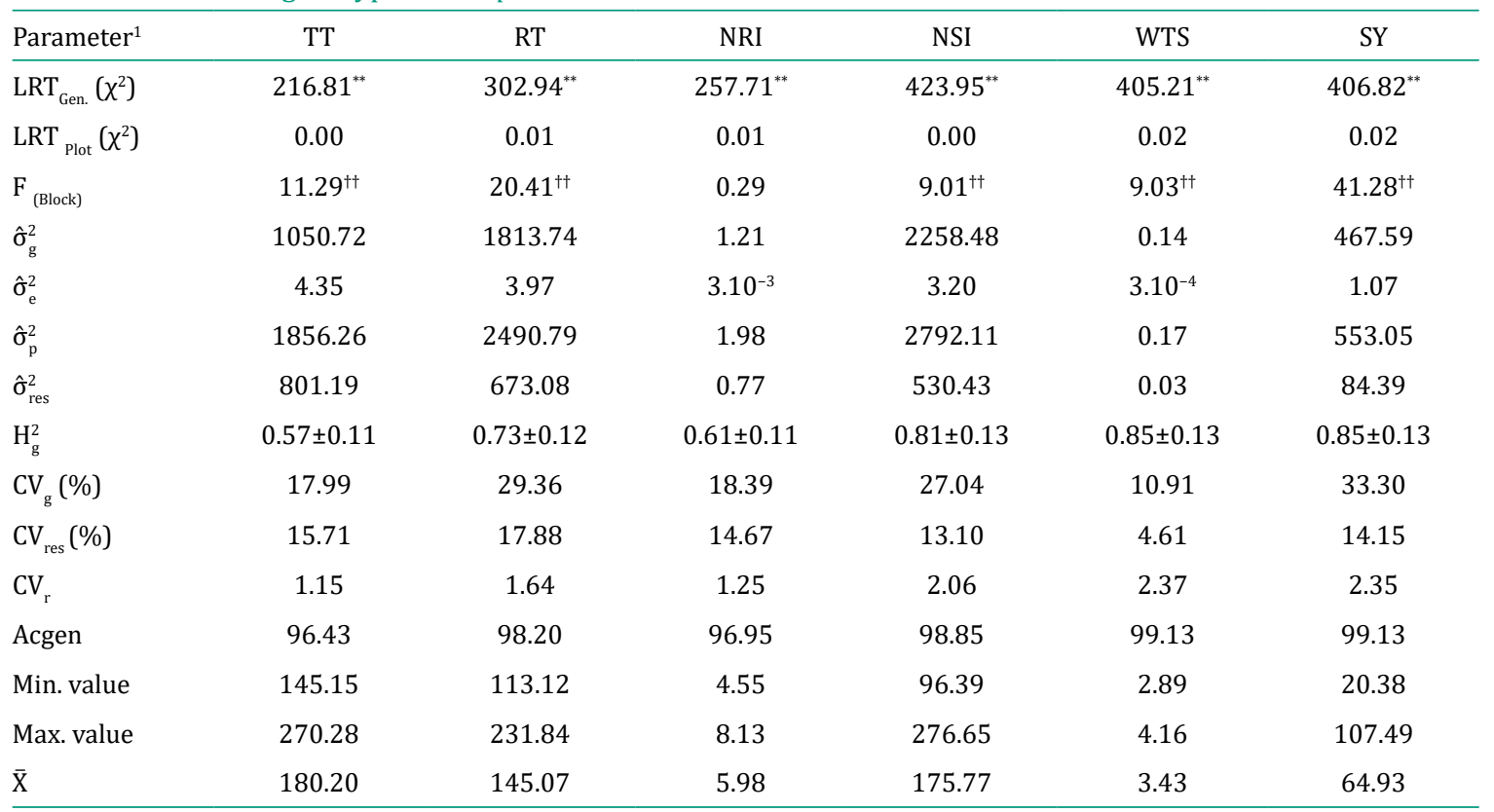

${ }^{1}$ Genotypic variance $\left(\hat{\sigma}_{g}^{2}\right)$; permanent environment variance $\left(\hat{\sigma}_{e}^{2}\right)$; phenotypic variance $\left(\hat{\sigma}_{p}^{2}\right)$; residual variance $\left(\hat{\sigma}_{\text {res }}^{2}\right)$; individual heritability in the broad sense $\left(\mathrm{H}_{\mathrm{g}}^{2}\right)$; genetic variation coefficient $\left(\mathrm{CV}_{\mathrm{g}}\right)$; residual variation coefficient $\left(\mathrm{CV}_{\text {res }}^{\mathrm{p}}\right)$; relative variation coefficient $\left(\mathrm{CV}_{\mathrm{r}}\right)$; genetic accuracy in genotype selection (Acgen); overall mean $(\bar{X})$.

${ }^{* *}$ Significant in the likelihood ratio test, considering $1 \%$ probability by the Chi-square test $\left(\chi^{2}\right)$ with 1 degree of freedom.

${ }^{+\dagger}$ Significant at $\mathrm{P}<0.01$, by the Snedecor F test. 
Table 2 - Estimates of genotypic correlations between number of total tillers (TT), reproductive tillers (RT), number of racemes per inflorescence (NRI), number of seeds per inflorescence (NSI), weight of a thousand seeds (WTS), and seed yield (SY), in nineteen genotypes of Paspalum

\begin{tabular}{lcccccc}
\hline & TT & RT & NRI & NSI & WTS & SY \\
\hline TT & - & $0.987^{* *}$ & $0.569^{*}$ & 0.399 & -0.362 & $0.495^{*}$ \\
RT & - & $0.614^{* *}$ & 0.427 & -0.332 & $0.769^{* *}$ \\
NRI & & - & $0.598^{* *}$ & -0.351 & 0.451 \\
NSI & & & - & $-0.561^{*}$ & $0.794^{* *}$ \\
WTS & & & & - & -0.105 \\
SY & & & & & - \\
\hline
\end{tabular}

** Significant at $\mathrm{P}<0.01$; ${ }^{*}$ Significant at $\mathrm{P}<0.05$, by the $\mathrm{t}$ test.

Table 3 - Mean for six different seed yield traits of nineteen Paspalum genotypes grouped into three clusters

\begin{tabular}{lccc}
\hline \multirow{2}{*}{ Trait } & \multicolumn{3}{c}{ Mean of clusters $^{1}$} \\
\cline { 2 - 4 } & $\mathrm{C}_{\mathrm{I}}$ & $\mathrm{C}_{\text {II }}$ & $\mathrm{C}_{\text {III }}$ \\
\hline TT & 163.91 & 213.83 & 273.75 \\
RT & 128.86 & 179.36 & 234.75 \\
NRI & 5.49 & 7.54 & 6.55 \\
NSI & 153.29 & 242.16 & 169.00 \\
WTS & 3.52 & 3.11 & 3.41 \\
SY & 57.28 & 85.25 & 90.69 \\
\hline
\end{tabular}

TT - total tillers (number plant ${ }^{-1}$ ); RT - reproductive tillers (number plant ${ }^{-1}$ ); NRI - number of racemes per inflorescence (number inflorescence ${ }^{-1}$ ); NSI - number of seeds per inflorescence (number inflorescence-1); WTS - weight of a thousand seeds (g); SY - seed yield ( $\mathrm{g} \mathrm{plant}^{-1}$ ).

${ }^{1} \mathrm{C}_{\mathrm{I}}=10 \mathrm{E} 3061,10 \mathrm{E} 3084,10 \mathrm{E} 3016, \mathrm{H} 12,10 \mathrm{E} 20104,10 \mathrm{E} 2058,10 \mathrm{E} 2084,10 \mathrm{E} 3020,10 \mathrm{E} 3077,10 \mathrm{E} 3031,10 \mathrm{E} 202,10 \mathrm{E} 3087,10 \mathrm{E} 3040$, and $10 \mathrm{E} 3093 ; \mathrm{C}_{\mathrm{II}}=\mathrm{H} 13, \mathrm{H} 22$, Azulão, and Baio; $\mathrm{C}_{\mathrm{III}}=\mathrm{H} 20$.

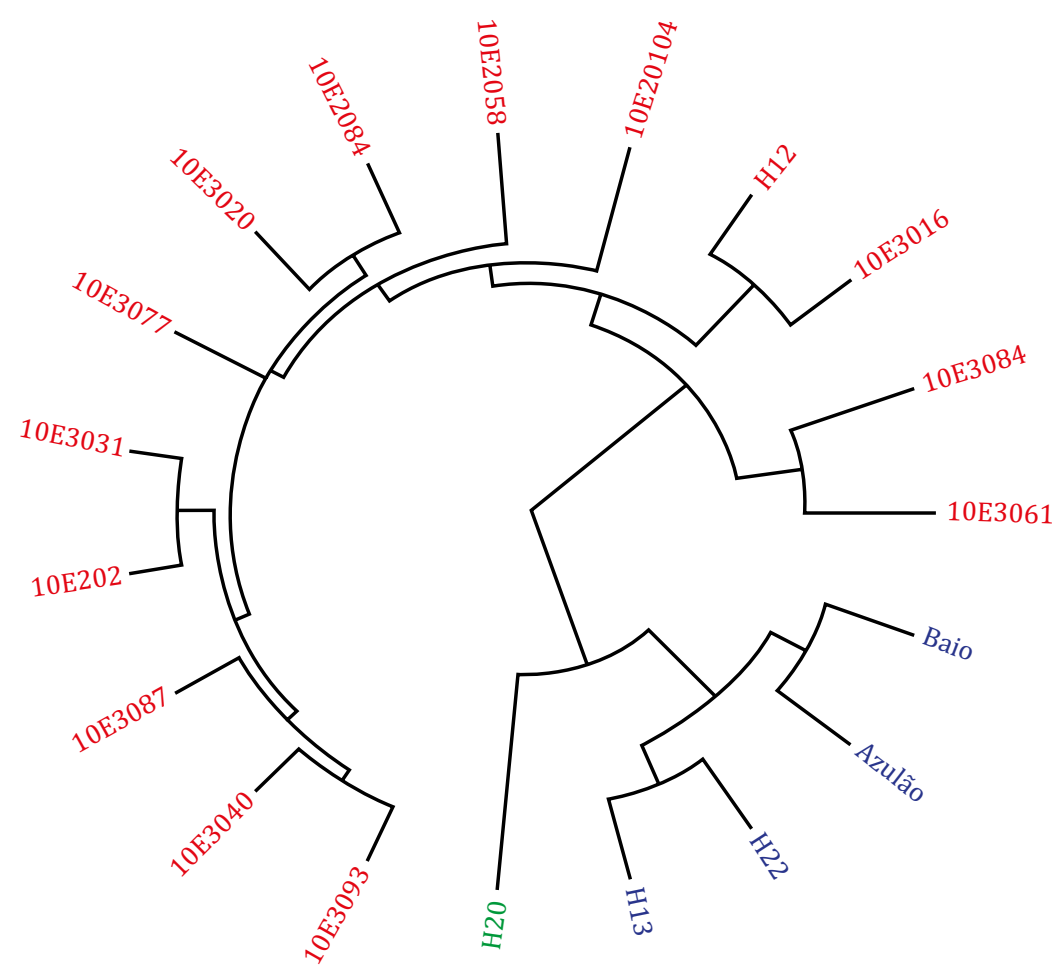

$\mathrm{C}_{\mathrm{I}}=10 \mathrm{E} 3061,10 \mathrm{E} 3084,10 \mathrm{E} 3016, \mathrm{H} 12,10 \mathrm{E} 20104,10 \mathrm{E} 2058,10 \mathrm{E} 2084,10 \mathrm{E} 3020,10 \mathrm{E} 3077,10 \mathrm{E} 3031,10 \mathrm{E} 202,10 \mathrm{E} 3087,10 \mathrm{E} 3040$, and $10 \mathrm{E} 3093 ; \mathrm{C}_{\mathrm{II}}=\mathrm{H} 13, \mathrm{H} 22$, Azulão, and Baio; $\mathrm{C}_{\mathrm{III}}=\mathrm{H} 20$.

Figure 1 - Dendrogram obtained by the Ward's clustering method based on the Mahalanobis distance $\left(\mathrm{D}_{\mathrm{iii}}^{2}\right)$ among nineteen Paspalum genotypes for the quantitative seed yield traits. 
10E2058, 10E2084, 10E3020, 10E3077, 10E3031, 10E202, 10E3087, 10E3040, and 10E3093. This group had the lowest values for all the evaluated traits, except WTS (Table 3). Cluster II $\left(\mathrm{C}_{\mathrm{II}}\right)$ was made up of four genotypes (H13, H22, Azulão, and Baio) and represented $21.1 \%$ of the total genotypes. These genotypes exhibited high values for NRI and NSI (Table 3 ). Cluster III $\left(\mathrm{C}_{\mathrm{III}}\right)$ consisted solely of one genotype (H20) and represented $5.3 \%$ of the total genotypes. This genotype showed the highest SY and high tillering (TT), passing these on to the reproductive stage (RT) (Table 3).

Among the 19 Paspalum genotypes, the seven best individuals (36.84\% of the total) were classified using the BLUP methodology, identifying those with the highest genetic gain (Table 4). In comparison with the overall average, the predicted genetic gains and the new estimated averages were higher in all the evaluated traits.

The selection based on genetic values for TT presented genetic gains that varied from 32.44 to 90.08 , raising the new average by $49.99 \%$ (Table 4 ). The best genotype was H20, which increased the new average to 270.28 . The lowest value was found in the 10E202 genotype, which showed predicted gains of approximately 32.44 .

It was found that the same genotypes previously selected for TT also had the same ordering for RT (Table 4). Genetic correlations between these traits were high $(r=0.987$; Table 2). The genetic gain for RT ranged from 32.97 to 86.77 and raised the new average by 59.81\%. The best genotype was $\mathrm{H} 20$, which increased the new average to 231.84. The lowest value was found in the 10E202 genotype, which presented predicted gains of 32.97 .

For NRI, the seven best genotypes showed variations from 1.16 to 2.15 and raised the new average by $35.95 \%$ (Table 4). The best genotype was H22, which raised the new average to 8.13. The lowest value was found in the H20 genotype, which presented predicted gains of about 7.13.

The genetic gain for NSI varied from 46.75 to 100.88 and raised the new average by $26.60 \%$ (Table 4 ). The best genotype was Azulão, which increased the new average to 276.65. The Baio genotype was the second best and showed a genetic gain of 93.24 , raising the new average to 269.02 . The lowest value was found in the 10E20104 genotype, which had predicted gains below 50, indicating that this genotype would not be advantageous for significant advances in NSI.

Selection in the WTS character showed genotypes resulting from the crossings between $P$. plicatulum $4 \mathrm{c}-4 \mathrm{x} \times$ P. guenoarum ecotypes Azulão and Baio (Table 4). Genotype 10E3084 had the best performance and showed promise in terms of genetic gains, which ranged from 0.40 to $0.73 \mathrm{~g}$, raising the new average by $21.28 \%$.

The ordering was carried out considering the objective of the program, which is to increase the expression of the SY trait. The genetic gain in this trait varied from 21.47 to $42.56 \mathrm{~g}$ of seeds per plant, thereby increasing the new average by $33.07 \%$ (Table 4). The ecotype Azulão had the best performance in SY (highlighted in the expression of NSI and RT), raising the new average to $107.49 \mathrm{~g}$. The hybrid 10E3077 was the second best in terms of WTS and NRI traits, raising the new average to $99.99 \mathrm{~g}$. The hybrid H20 (with high values of TT and RT) came in third and raised the new average to $96.81 \mathrm{~g}$, followed by the ecotype Baio (highlighted in NSI and NRI), which raised the new average to $92.93 \mathrm{~g}$. These four genotypes were the only ones that increased the new averages above $40 \%$ for SY.

\section{Discussion}

In Paspalum species, most of the traits related to SY are inflorescence traits (NSI and WTS) and reproductive tillers (RT) (Lopes and Franke 2011a,b), which can serve as selection indicators for breeding programs aimed at forage seed production (Biligetu et al., 2013).

Our results showed that the environmental effects did not prevail over nor affect the genetic variability of the genotypes in our experiment. The wide variability among the genotypes studied, combined with good environmental control, resulted in high coefficients of individual broad sense heritability $\left(\mathrm{H}_{\mathrm{g}}^{2}\right)$ for all traits (Table 1). These results are favorable for selection and are also of great importance 
Table 4 - Predicted genotypic effect (g), genotypic value $(\mathrm{u}+\mathrm{g})$, genetic gains (gain), percentage genetic gains (pgg), and new average $\left(\overline{\mathrm{X}}_{\text {new }}\right)$ of the seven best genotypes of Paspalum for seed yield traits

\begin{tabular}{|c|c|c|c|c|c|c|}
\hline Order & Genotype & g & $u+g$ & Gain & $\operatorname{pgg}(\%)^{1}$ & $\overline{\mathrm{X}}_{\text {new }}$ \\
\hline & \multicolumn{6}{|c|}{ Total tillers (number plant ${ }^{-1}$ ) } \\
\hline 1 & $\mathrm{H} 20$ & 90.08 & 270.28 & 90.08 & 49.99 & 270.28 \\
\hline 2 & $\mathrm{H} 13$ & 36.35 & 216.55 & 63.21 & 35.08 & 243.41 \\
\hline 3 & $\mathrm{H} 22$ & 36.01 & 216.21 & 54.14 & 30.04 & 234.35 \\
\hline 4 & Baio & 32.30 & 212.51 & 48.68 & 27.01 & 228.89 \\
\hline 5 & Azulão & 24.84 & 205.04 & 43.91 & 24.37 & 224.12 \\
\hline 6 & 10E3031 & 5.53 & 185.74 & 37.52 & 20.82 & 217.72 \\
\hline \multirow[t]{2}{*}{7} & 10E202 & 1.97 & 182.17 & 32.44 & 18.00 & 212.64 \\
\hline & \multicolumn{6}{|c|}{ Reproductive tillers (number plant ${ }^{-1}$ ) } \\
\hline 1 & $\mathrm{H} 20$ & 86.77 & 231.84 & 86.77 & 59.81 & 231.84 \\
\hline 2 & $\mathrm{H} 13$ & 41.97 & 187.04 & 64.37 & 44.37 & 209.44 \\
\hline 3 & $\mathrm{H} 22$ & 38.93 & 183.99 & 55.89 & 38.53 & 200.96 \\
\hline 4 & Azulão & 26.59 & 171.66 & 48.57 & 33.48 & 193.63 \\
\hline 5 & Baio & 25.24 & 170.30 & 43.90 & 30.26 & 188.97 \\
\hline 6 & 10E3031 & 8.26 & 153.32 & 37.96 & 26.17 & 183.02 \\
\hline \multirow[t]{2}{*}{7} & 10E202 & 3.03 & 148.10 & 32.97 & 22.73 & 178.04 \\
\hline & \multicolumn{6}{|c|}{ Number of racemes per inflorescence (number inflorescence ${ }^{-1}$ ) } \\
\hline 1 & $\mathrm{H} 22$ & 2.15 & 8.13 & 2.15 & 35.95 & 8.13 \\
\hline 2 & Baio & 2.06 & 8.04 & 2.11 & 35.28 & 8.08 \\
\hline 3 & $\mathrm{H} 13$ & 1.09 & 7.07 & 1.77 & 29.60 & 7.74 \\
\hline 4 & $\mathrm{H} 12$ & 0.90 & 6.87 & 1.55 & 25.92 & 7.53 \\
\hline 5 & Azulão & 0.75 & 6.73 & 1.39 & 23.24 & 7.37 \\
\hline 6 & 10E3087 & 0.60 & 6.58 & 1.26 & 21.07 & 7.23 \\
\hline \multirow[t]{2}{*}{7} & $\mathrm{H} 20$ & 0.56 & 6.53 & 1.16 & 19.40 & 7.13 \\
\hline & \multicolumn{6}{|c|}{ Number of seeds per inflorescence (number inflorescence ${ }^{-1}$ ) } \\
\hline 1 & Azulão & 100.88 & 276.65 & 100.88 & 57.39 & 276.65 \\
\hline 2 & Baio & 85.61 & 261.38 & 93.24 & 53.05 & 269.02 \\
\hline 3 & $\mathrm{H} 22$ & 40.35 & 216.12 & 75.61 & 43.02 & 251.38 \\
\hline 4 & $\mathrm{H} 13$ & 35.60 & 211.38 & 65.61 & 37.33 & 241.38 \\
\hline 5 & $10 \mathrm{E} 3016$ & 27.25 & 203.03 & 57.94 & 32.96 & 233.71 \\
\hline 6 & 10E3077 & 23.84 & 199.62 & 52.26 & 29.73 & 228.03 \\
\hline \multirow[t]{2}{*}{7} & 10E20104 & 13.71 & 189.49 & 46.75 & 26.60 & 222.52 \\
\hline & \multicolumn{6}{|c|}{ Weight of a thousand seeds (g) } \\
\hline 1 & $10 \mathrm{E} 3084$ & 0.73 & 4.16 & 0.73 & 21.28 & 4.16 \\
\hline 2 & $10 \mathrm{E} 2084$ & 0.64 & 4.06 & 0.68 & 19.83 & 4.11 \\
\hline 3 & $10 \mathrm{E} 3077$ & 0.45 & 3.88 & 0.61 & 17.78 & 4.04 \\
\hline 4 & $10 \mathrm{E} 3087$ & 0.35 & 3.78 & 0.54 & 15.74 & 3.97 \\
\hline 5 & $10 \mathrm{E} 3020$ & 0.25 & 3.68 & 0.48 & 13.99 & 3.91 \\
\hline 6 & $10 \mathrm{E} 202$ & 0.23 & 3.66 & 0.44 & 12.83 & 3.87 \\
\hline \multirow[t]{2}{*}{7} & $10 \mathrm{E} 3031$ & 0.12 & 3.55 & 0.40 & 11.66 & 3.82 \\
\hline & \multicolumn{6}{|c|}{ Seed yield $\left(\mathrm{g} \mathrm{plant}^{-1}\right.$ ) } \\
\hline 1 & Azulão & 42.56 & 107.49 & 42.56 & 65.55 & 107.49 \\
\hline 2 & $10 \mathrm{E} 3077$ & 27.55 & 92.48 & 35.06 & 54.00 & 99.99 \\
\hline 3 & $\mathrm{H} 20$ & 25.52 & 90.45 & 31.88 & 49.10 & 96.81 \\
\hline 4 & Baio & 16.38 & 81.31 & 28.00 & 43.12 & 92.93 \\
\hline 5 & $10 \mathrm{E} 3040$ & 14.73 & 79.66 & 25.35 & 39.04 & 90.28 \\
\hline 6 & $\mathrm{H} 22$ & 13.42 & 78.35 & 23.36 & 35.98 & 88.29 \\
\hline 7 & $\mathrm{H} 12$ & 10.10 & 75.03 & 21.47 & 33.07 & 86.39 \\
\hline
\end{tabular}

${ }^{1}$ Percentage genetic gain over overall mean $(\overline{\mathrm{X}})$. 
for the improvement of the crop, as they guide us towards possibilities of using different selection methods and allow us to estimate the genetic progress (Resende and Duarte, 2007). In evaluating seed production of Dactylis glomerata L. populations, Șeker et al. (2014) found high heritability values (0.64), which showed strong genetic control of the trait at an individual level, suggesting that environmental factors had a little effect on heredity. However, the selection efficacy depends not only on heritability but also on genetic advancement (Pereira et al., 2017). The high coefficient of genetic variation in conjunction with high heritability provides more information than other parameters alone (Shabanimofrad et al., 2013).

The presence of genetic variability can be confirmed and measured by the values obtained in the genetic variation coefficient $\left(\mathrm{CV}_{\mathrm{g}}\right)$, indicating that the median fraction of the genetic variances was extracted from the total phenotypic variation. From another perspective, high $\mathrm{CV}_{\mathrm{g}}$ values are desired, as it quantifies the magnitude of the genetic variation available to enable gains from selection (Carvalho et al., 2016). According to Sebbenn et al. (1998), values above $7.0 \%$ are considered high and, in this study, all the $\mathrm{CV}_{\mathrm{g}}$ values of the traits considered were higher than $10.91 \%$ (Table 1 ). This confirms the potential of the hybrids for selection by means of the genetic gain obtained through the application of adequate selection procedures.

The joint evaluation of $\mathrm{CV}_{\mathrm{g}}$ and $\mathrm{CV}_{\text {res }}$ is extremely relevant for breeding programs based on selection, as it has a direct effect on selective accuracy. The coefficient of relative variation $\left(\mathrm{CV}_{\mathrm{r}}\right)$, or the variation index, represents the ratio between $\mathrm{CV}_{\mathrm{g}}$ and $\mathrm{CV}_{\text {res }}$. Thus, it is not influenced by the trait average. $\mathrm{A} \mathrm{CV}_{\mathrm{r}}$ close to or higher than 1.0 is favorable to obtain gains from the selection of a given character (Resende and Duarte, 2007). As seed production is a complex process, $\mathrm{CV}_{\mathrm{r}}$ can be used to indicate a trait to be used for selection when many variables are evaluated. Thus, RT, NSI, and WTS could be utilized to carry out selective processes.

Selective accuracy (Acgen) is useful for the simultaneous identification of environmental and genetic variation, and values above $70 \%$ are desirable in genotype evaluation experiments (Resende, 2007). Thus, the accuracy values obtained in this study (above 96.43\%) are promising. This shows that the genotypic values obtained in this study were very close to the real genotypic values, making it possible to select the genotypes, with precision and reliability, to be used in breeding programs or to serve as an initial seed source for the crops (Resende, 2002). In these cases, the phenotypic selection method will be the most effective in selecting superior genotypes for SY (Pimentel et al., 2014).

Understanding the association of different traits with SY helps in the selection process, with more accuracy and precision. The high and positive correlations between RT $\times$ SY and NSI $\times$ SY indicate that better selection of any of these traits may provide favorable changes in SY. These traits are described by Humphreys and Riveros (1986) as some of the main components of SY of forage grasses. Genetic correlation between these traits denotes the degree of genetic association between them, and this allows the breeder to perform indirect selection when a trait presents a favorable and significant correlation with another trait of interest, and it is easy to evaluate. Thus, due to the high genetic correlation and heritability presented by RT and NSI, both can be used as selection criteria, with genetic gains for SY at the same time. High association between the RT and SY was also confirmed in Panicum maximum (Canto et al., 2012), Paspalum urvillei (Lopes and Franke, 2011a), Paspalum notatum (Lopes and Franke, 2011b), and Brachiaria brizantha (Quadros et al., 2010).

The WTS and NSI traits were negatively correlated with each other. They showed competitive relationship within the clump (Nakagawa, 2014), and the increase of one trait leads to the decrease of the other due to the plasticity or compensatory capacity of the plant in regulating yield components. Furthermore, there is evidence that seed size plays an important role in regulating the genetic control of the number of seeds produced per inflorescence (Sadras, 2007).

The differences in the average values of the traits evaluated in this study shows the genetic dissimilarity and SY performance of Paspalum genotypes, resulting in the formation of three different clusters. As can be seen, Cluster I $\left(\mathrm{C}_{\mathrm{I}}\right)$ had the highest number of genotypes and was also characterized by the lower values of TT, RT, NRI, NSI, except for WTS, and lower SY. Cluster II $\left(\mathrm{C}_{\mathrm{II}}\right)$ brought together 
genotypes with good SY, with intermediate TT, relatively lower RT, higher NSI, and lower WTS. The classification of hybrid $\mathrm{H} 20$ in $\mathrm{C}_{\mathrm{III}}$, followed by the classification of hybrids $\mathrm{H} 13$ and $\mathrm{H} 22$ in $\mathrm{C}_{\mathrm{II}}$, showed that the hybridization between P. plicatulum 4c-4x and P. guenoarum cv. Rojas can provide genotypes with higher SY. On the other hand, the genotypes in $\mathrm{C}_{1}$ were formed mainly by the hybrids originated from the crossings between P. plicatulum 4c-4x and P. guenoarum ecotypes Azulão and Baio. These genotypes showed greater genetic distance compared with the other genotypes, mainly due to traits intrinsic to the population patterns of tillers and components of inflorescence. As for the classification of ecotypes Azulão and Baio in $\mathrm{C}_{\mathrm{II}}$ this result suggests that SY may not have been transmitted to their progeny, as they were all classified in $\mathrm{C}_{\mathrm{I}}$.

High genetic gains can be obtained by selecting individuals based on their genotypic values for a desired trait. The use of BLUP to estimate genetic values allowed for the selection of genotypes with higher averages for all traits. Gains resulting from selection can be approximately $60 \%$ for the traits that best correlate with SY (RT and NSI), which can be attributed to the fact that the genetic resources evaluated have not yet been fully domesticated. These results indicate the existence of great genetic dissimilarity to be explored in the genetic improvement program of the species. It should be noted that both traits showed high estimates of $\mathrm{H}_{\mathrm{g}^{2}}^{2}$ and heritability can be used to directly predict genetic gain, regardless of the selection method, and, consequently, helps in the decision making for genetic improvement of crops (Ramalho et al., 2012).

The main SY components of Paspalum are TT, RT, NSI, and WTS (Lopes and Franke 2011a,b; Lopes et al., 2018). The use of these traits favors the selection of superior performance genotypes, through indirect selection, in traits that are difficult to select and measure, such as SY. The majority of the studies in perennial forage species focuses on forage production rather than SY (Majidi et al., 2009). Our results fill this void by providing crucial information related to SY that contributes to the selection process to guide genetic improvement of Paspalum. Our results show that the structural characteristics of the plant, the number of vegetative tillers that pass on to the reproductive stage, can theoretically be used to predict SY prior to the beginning of flowering with high accuracy and precision.

\section{Conclusions}

High level of variability exists for seed yield-related traits in the crosses of P. plicatulum $\times$ P. guenoarum species. Number of seeds/inflorescence and reproductive tillers/plant showed high correlation with seed yield/plant, and these traits can be used for indirect selection of seed yield. High genetic values for important seed yield-related traits indicate that the hybrids $\mathrm{H} 20, \mathrm{H} 22$, and $\mathrm{H} 13$ and ecotypes Azulão and Baio can be used as excellent materials for genetic improvement of Paspalum sp. Plicatula group in the future.

\section{Conflict of Interest}

The authors declare no conflict of interest.

\section{Author Contributions}

Conceptualization: R.R. Lopes and L.B. Franke. Data curation: R.R. Lopes, C.H.L. Souza, P. Bertoncelli, L.A. Graminho, M.R. Ávila and E.A.M. Motta. Formal analysis: R.R. Lopes, C.H.L. Souza, P. Bertoncelli, L.A. Graminho, M.R. Ávila, E.A. Pereira and E.A.M. Motta. Funding acquisition: L.B. Franke. Investigation: R.R. Lopes, L.B. Franke, C.H.L. Souza, L.A. Graminho, M.R. Ávila and E.A. Pereira. Methodology: R.R. Lopes, L.B. Franke and P. Bertoncelli. Project administration: R.R. Lopes and L.B. Franke. Resources: L.B. Franke. Supervision: R.R. Lopes and L.B. Franke. Visualization: E.A. Pereira and E.A.M. Motta. Writing-original draft: R.R. Lopes, C.H.L. Souza, P. Bertoncelli, L.A. Graminho, M.R. Ávila, E.A. Pereira and E.A.M. Motta. Writing-review \& editing: R.R. Lopes, L.B. Franke, C.H.L. Souza, P. Bertoncelli, L.A. Graminho, M.R. Ávila, E.A. Pereira and E.A.M. Motta. 


\section{Acknowledgments}

This work was supported by Coordenação de Aperfeiçoamento de Pessoal de Nível Superior (CAPES; process 007488/2011-35). The authors thank Marcos Deon Vilela de Resende (Embrapa Florestas) and Andrei Caíque Nunes (UFV) for helping with statistical analysis (SELEGEN-REML/BLUP software).

\section{References}

Aguilera, P. M.; Sartor, M. E.; Galdeano, F.; Espinoza, F. and Quarin, C. L. 2011. Interspecific tetraploid hybrids between two forage grass species: sexual Paspalum plicatulum and apomictic P. guenoarum. Crop Science 51:1544-1550. https://doi.org/10.2135/cropsci2010.10.0610

Biligetu, B.; Schellenberg, M. P.; McLeod, J. G. and Wang, Z. 2013. Seed yield variation in plains rough fescue (Festuca hallii (Vasey) Piper) populations and its relation with phenotypic characteristics and environmental factors. Grass and Forage Science 68:589-595. https://doi.org/10.1111/gfs.12012

Boelt, B. and Studer, B. 2010. Breeding for grass seed yield. p.161-174. In: Fodder crops and amenity grasses. Boller, B.; Posselt, U. K. and Veronesi, F., eds. Springer Publishing, New York City.

Brasil. 2009. Regras para análise de sementes. MAPA/ACS, Brasília, DF.

Canto, M. W.; Barth Neto, A.; Pancera Júnior, E. J.; Gasparino, E. and Boleta, V. S. 2012. Produção e qualidade de sementes do capim-mombaça em função da adubação nitrogenada. Bragantia 71:430-437. https://doi.org/10.1590/ S0006-87052012005000032

Carvalho, L. P.; Farias, F. J. C.; Morello, C. L. and Teodoro, P. E. 2016. Uso da metodologia REML/BLUP para seleção de genótipos de algodoeiro com maior adaptabilidade e estabilidade produtiva. Bragantia 75:314-321. https://doi.org/10.1590/1678-4499.275

CQFS-RS/SC - Comissão de Química e Fertilidade do Solo RS/SC, Núcleo Regional Sul da Sociedade Brasileira de Ciência do Solo. 2004. Manual de adubação e de calagem para os estados do Rio Grande do Sul e Santa Catarina. CQFS-RS/SC, Porto Alegre, RS.

Hand, M. L. and Koltunow, A. M. 2014. The genetic control of apomixis: Asexual seed formation. Genetics 197:441-450. https://doi.org/10.1534/genetics.114.163105

Huber, K. G. C.; Dall'Agnol, M.; Motta, E. A. M.; Pereira, E. A.; Ávila, M. R.; Perera, M. Z. and Santos, T. N. 2016. Variabilidade agronômica e seleção de progênies $\mathrm{F}_{1}$ de Paspalum. Revista Brasileira de Ciências Agrárias 11:374-380. https://doi.org/10.5039/agraria.v11i4a5391

Humphreys, L. R. and Riveros, F. 1986. Tropical pasture seed production. FAO plant production and protection paper n. 8. FAO, Roma, Italy.

Lopes, R. R. and Franke, L. B. 2011a. Produção de sementes de quatro ecótipos de Paspalum nativos do Rio Grande do Sul. Revista Brasileira de Zootecnia 40:20-30. https://doi.org/10.1590/S1516-35982011000100004

Lopes, R. R. and Franke, L. B. 2011b. Correlação e análise do coeficiente de trilha dos componentes do rendimento de sementes de grama-forquilha. Revista Brasileira de Zootecnia 40:972-977. http://doi.org/10.1590/S1516-35982011000500005

Lopes, R. R.; Franke, L. B.; Souza, C. H. L.; Bertoncelli, P.; Graminho, L. A. and Pereira, E. A. 2018. Genetic parameters and predicted gains with selection of interspecific hybrids of Paspalum for seed production. Crop Breeding and Applied Biotechnology 18:284-291. https://doi.org/10.1590/1984-70332018v18n3a42

Majidi, M. M.; Mirlohi, A. and Amini, F. 2009. Genetic variation, heritability and correlations of agro-morphological traits in tall fescue (Festuca arundinacea Schreb.). Euphytica 167:323-331. https://doi.org/10.1007/s10681-009-9887-6

Motta, E. A. M.; Dall'Agnol, M.; Nascimento, F. L.; Pereira, E. A.; Machado, J. M.; Barbosa, M. R.; Simioni, C. and Ferreira, P. B. 2016. Forage performance of Paspalum hybrids from an interspecific cross. Ciência Rural 46:1025-1031. https://doi.org/10.1590/0103-8478cr20150232

Motta, E. A. M.; Dall'Agnol, M.; Pereira, E. A.; Machado, J. M. and Simioni, C. 2017. Valor forrageiro de híbridos interespecíficos superiores de Paspalum. Revista Ciência Agronômica 48:191-198.

Nakagawa, J. 2014. Os componentes da produtividade de sementes. Informativo Abrates 24:15-21.

Novo, P. E.; Acuña, C. A.; Quarin, C. L.; Urbani, M. H.; Marcón, F. and Espinoza, F. 2017. Hybridization and heterosis in the Plicatula group of Paspalum. Euphytica 213:198. https://doi.org/10.1007/s10681-017-1983-4

Ortiz, J. P. A.; Quarin, C. L.; Pessino, S. C.; Acuña, C.; Martínez, E. J.; Espinoza, F.; Hojsgaard, D. H.; Sartor, M. E.; Cáceres, M. E. and Pupilli, F. 2013. Harnessing apomictic reproduction in grasses: What we have learned from Paspalum. Annals of Botany 112:767-787. https://doi.org/10.1093/aob/mct152

Pereira, E. A. 2013. Melhoramento genético por meio de hibridizações interespecíficas no grupo Plicatula - Gênero Paspalum. Tese (D.Sc.). Universidade Federal do Rio Grande do Sul, Porto Alegre. 
Pereira, E. A.; Barros, T.; Volkmann, G. K.; Battisti, G. K.; Silva, J. A. G.; Simioni, C. and Dall'Agnol, M. 2012. Variabilidade genética de caracteres forrageiros em Paspalum. Pesquisa Agropecuária Brasileira 47:1533-1540. https://doi.org/10.1590/S0100-204X2012001000017

Pereira, E. A.; Dall'Agnol, M.; Saraiva, K. M.; Simioni, C.; Leães, A. P. S. and Silva, J. A. G. 2017. Genetic gain in apomictic species of the genus Paspalum. Revista Ceres 64:60-67. https://doi.org/10.1590/0034-737x201764010009

Pereira, E. A.; Dall'Agnol, M.; Simioni, C.; Machado, J. M.; Bitencourt, M. G. S.; Guerra, D.; Arenhardt, E. G. and Silva, J. A. G. 2015. Agronomic performance and interspecific hybrids selection of the genus Paspalum. Científica 43:388-395. https://doi.org/10.15361/1984-5529.2015v43n4p388-395

Pimentel, A. J. B.; Guimarães, J. F. R.; Souza, M. A.; Resende, M. D. V.; Moura, L. M.; Rocha, J. R. A. S. C. and Ribeiro, G. 2014. Estimação de parâmetros genéticos e predição de valor genético aditivo de trigo utilizando modelos mistos. Pesquisa Agropecuária Brasileira 49:882-890. https://doi.org/10.1590/S0100-204X2014001100007

Quadros, D. G.; Oliveira, G. C.; Oliveira, E. P.; Andrade, A. P.; Silva, A. V. and Stolben, E. 2010. Componentes da produção de sementes de duas cultivares de Brachiaria brizantha (Hochst. ex A. Rich.) Stapf nos cerrados da Bahia. Revista Científica de Produção Animal 12:19-22.

Ramalho, M. A. P.; Abreu, A. F. B.; Santos, J. B. and Nunes, J. A. R. 2012. Aplicações da genética quantitativa no melhoramento de plantas autógamas. UFLA, Lavras.

Resende, M. D. V. 2016. Software SELEGEN-REML/BLUP: a useful tool for plant breeding. Crop Breeding and Applied Biotechnology 16:330-339. https://doi.org/10.1590/1984-70332016v16n4a49

Resende, M. D. V. 2007. Software SELEGEN-REML/BLUP: sistema estatístico e seleção genética computadorizada via modelos lineares mistos. Embrapa Florestas, Colombo.

Resende, M. D. V. 2002. Genética, biométrica e estatística: no melhoramento de plantas perenes. Embrapa Informação Tecnológica, Brasília.

Resende, M. D. V. and Duarte, J. B. 2007. Precisão e controle de qualidade em experimentos de avaliação de cultivares. Pesquisa Agropecuária Tropical 37:182-194.

Sadras, V. 0. 2007. Evolutionary aspects of the trade-off between seed size and number in crops. Field Crops Research 100:125-138. https://doi.org/10.1016/j.fcr.2006.07.004

Santos, H. G.; Almeida, J. A.; Oliveira, J. B.; Lumbreras, J. F.; Anjos, L. H. C.; Coelho, M. R.; Jacomine, P. K. T.; Cunha, T. J. F and Oliveira, V. A. 2013. Sistema Brasileiro de Classificação de Solos. Empresa Brasileira de Pesquisa Agropecuária, CNPS, Rio de Janeiro.

Sartor, M. E.; Quarin, C. L. and Espinoza, F. 2009. Mode of reproduction of colchicine-induced Paspalum plicatulum tetraploids. Crop Science 49:1270-1276. https://doi.org/10.2135/cropsci2008.05.0270

Sebbenn, A. M.; Kageyama, P. Y. and Vencosvky, R. 1998. Variabilidade genética, sistema reprodutivo e estrutura genética especial em Genipa americana L. através de marcadores isoenzimáticos. Scientia Forestalis 53:15-30.

Şeker, H.; Yazici, A. and Uysal, P. 2014. Analysis of variability, heritability, and genetic advance in seed yield and related traits of orchardgrass (Dactylis glomerata L.) populations. Turkish Journal of Agriculture and Forestry 38:633-643. https://doi.org/10.3906/tar-1312-95

Shabanimofrad, M.; Rafii, M. Y.; Megat Wahab, P. E.; Biabani, A. R. and Latif, M. A. 2013. Phenotypic, genotypic and genetic divergence found in 48 newly collected Malaysian accessions of Jatropha curcas L. Industrial Crops and Products 42:543-551. https://doi.org/10.1016/j.indcrop.2012.06.023

Steiner, M. G.; Dall'Agnol, M.; Nabinger, C.; Scheffer-Basso, S. M.; Weiler, R. L.; Simioni, C.; Schifino-Wittmann, M. T. and Motta, E. A. M. 2017. Forage potential of native ecotypes of Paspalum notatum and P. guenoarum. Anais da Academia Brasileira de Ciências 89:1753-1760. https://doi.org/10.1590/0001-3765201720160662 